Düzgün, M., Kendal, E., Düz, Z., Hatipoğlu, A (2021): Identify of macro and trace elements in grain of some barley varieties and interpretation with biplot techique. Agriculture and Forestry, 67 (1): 115-124.

DOI: 10.17707/AgricultForest.67.1.10

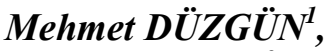

Enver KENDAL ${ }^{2}$, M. Zahir DÜZ $Z^{3}$, Abdülkerim HATIPOĞLU,

\title{
IDENTIFY OF MACRO AND TRACE ELEMENTS IN GRAIN OF SOME BARLEY VARIETIES AND INTERPRETATION WITH BIPLOT TECHNIQUE
}

\begin{abstract}
SUMMARY
The purpose of this study was to determine the content of some macro and trace elements in grain of spring barley cultivars, and to state the relationships between those elements. In this study macro and trace elements $(\mathrm{Ca}$, $\mathrm{K}, \mathrm{Mg}, \mathrm{Fe}, \mathrm{Zn}, \mathrm{Mn}, \mathrm{Si}, \mathrm{Sn}, \mathrm{Cu}, \mathrm{Cr}, \mathrm{Cd}, \mathrm{Ni}, \mathrm{V}, \mathrm{Pb}, \mathrm{As}$ and $\mathrm{Se}$ ) of barley cultivars were determined by inductively coupled plasma optic emission spektometry (ICP-OES) using grain. The grain samples were digested by microwave system, as well as. As and Se were determined by hydride system. The result of study showed that the content $\mathrm{Si}$ of barley cultivars are quite high, however, the concentrations toxic heavy metals of $\mathrm{Cd}, \mathrm{Pb}$ and as were determined to be below the limit values.

The biplot indicated that three group occurred among macro and trace element and the correlation of $\mathrm{Zn}$ with $\mathrm{Sn}, \mathrm{Cr}$ with $\mathrm{Ca}$ and $\mathrm{Fe}, \mathrm{Ca}$ with $\mathrm{Fe}$ and $\mathrm{Pb}$ was significant and positively, while $\mathrm{V}$ with $\mathrm{Si}$ was significant and negatively. On the other hand, the study showed that Samyeli is the best cultivar based on macro and trace element concentrations and this variety can be used in animal husbandry.
\end{abstract}

Keywords: Cultivar, food, macro, ICP-OES, Heavy metal

\footnotetext{
${ }^{1}$ Mehmet Düzgün, GAP International Agricultural Research and Training Center, Diyarbakır, (e_mail: mehmetdzgn@ymail.com; mehmet.duzgun@tarimorman.gov.tr); TURKEY

${ }^{2}$ Enver Kendal, Mardin Artuklu University, Kiziltepe VTHS, Department of Crops and Animal Production, Mardin, (corresponding author: enver21_1@ @otmail.com), TURKEY

${ }^{3}$ M. Zahir Düz, Dicle University, Faculty of Science, Department of Chemistry, Diyarbakır, TURKEY

${ }^{4}$ Abdülkerim Hatipoğlu, Mardin Artuklu University, Faculty of Health Sciences, Department of Nutrition and Dietetics, Mardin, TURKEY

Notes: The authors declare that they have no conflicts of interest. Authorship Form signed online.

Recieved:31/08/2020

Accepted:18/02/2021
} 


\section{INTRODUCTION}

Barley is the most important food source for animal con-sumption, and historically has been an important food source in many parts of the World, as well as Turkey (Jākobsone et al., 2018; Kendal et al., 2019). Transfer of macro and trace elements to the feeding chain of animals are significantly affected by the geological origin of the soils and the ground water basin as well as the environmental conditions and genetic difference of Barley varieties (Markova Ruzdik et al., 2015). Since heavy metals are mobile and easily absorbed by plants in the environment, they are transmitted to the animal body through nourishment.

The studies on the transfer of chemical contaminants through the food chain provide useful information for the development of surveillance programs aimed at ensuring the safety of the food supply and minimising human exposure to toxic agents (Cubadda and Raggi, 2005). It is well known that foods take up trace metals from soils, fertilizers, air, and industrial process, transportation, and package materials. Heavy metals are mobile and easily taken up by plants in the environment (Khairiah et al., 2004; Chojnacka et al., 2005; Demirel et al., 2008) When considering different kinds of soil pollutants, heavy metals represent a special hazard because of their persistence and toxicity (Adriano, 2001). For the human body, certain heavy metals are essential for the biological systems as structural and catalytic components of proteins and enzymes like zinc $(\mathrm{Zn})$ and copper $(\mathrm{Cu})$, and others are contaminants such as cadmium $(\mathrm{Cd})$, arsenic (As), lead $(\mathrm{Pb})$, chromium $(\mathrm{Cr})$, nickel $(\mathrm{Ni})$ and so on (Rana,2008; McLaughlin, 1999). Soil behaves as a sink for heavy metals arriving by the aerial deposition of particles emitted by urban and industrial activities (Bermudez et al., 2010; Schuhmacher et al., 2009) as well as from agricultural practices (Chen et al., 2008; Mico et al., 2006). High pollution levels in soils can lead to phytotoxicity and result in the transfer of heavy metals to the human diet from crop uptake or soil ingestion by grazing livestock (Abrahams, 2002; Kabata-Pendias and Mukherjee 2007). Food and Agriculture Organization (FAO) and World Health Organization (WHO), European Commission (EC) and other regulatory bodies of other countries strictly regulate the allowable concentrations or maximum permitted concentrations of toxic heavy metals in foodstuffs (FAO/WHO 1984, EC, 1989). Reference daily intakes for 9 significant elements have been established: calcium $(1000 \mathrm{mg})$, chromium $(120 \mu \mathrm{g})$, copper $(2 \mathrm{mg})$, iron $(18$ $\mathrm{mg}$ ), potassium (3500 mg), magnesium (400 mg), manganese (2 mg), selenium $(70 \mu \mathrm{g})$ and zinc $(15 \mathrm{mg})$ (Mindel, 2000, Cernohorsky et al., 2008). However, heavy metal levels in the soil for lead $(300 \mathrm{mg} / \mathrm{kg})$, cadmium $(3 \mathrm{mg} / \mathrm{kg})$, chromium (100 mg/kg), Copper (140 mg/kg), nicel $(75 \mathrm{mg} / \mathrm{kg})$, zinc $(300 \mathrm{mg} / \mathrm{kg})$ were established (Anonymus 1). The impact of heavy metals on the environment is greatly dependent on their speciation in soil solution and solid phase which determine their environmental availability, toxicity, migration - accumulation phenomena, geochemical transfer and mobility pathways (Druteikienè et al., 2002; Pinto at al., 2004). Uptake and bioaccumulation of heavy metals by plants 
is of importance because of an impact on soils by anthropogenic emissions and its consequence for human uptake (Bradl, 2005).

\section{MATERIAL AND METHODS}

In the study, four barley cultivars (Alt1kat, Samyeli, Şahin-91, Sur-93) used and the samples of grain of these cultivars was taken from the Department of field crops department of GAP International Agricultural Research and Training Center.

Table 1. Sample digestion program for barley and soil

\begin{tabular}{cccl}
\hline Step(barley) & Time $(\min )$ & $\mathrm{T}\left({ }^{\circ} \mathrm{C}\right)$ & Power(W) \\
\hline 1 & $20: 00$ & 180 & 1200 \\
2 & $20: 00$ & 180 & 1200 \\
\hline Step(soil) & & & \\
1 & $20: 00$ & 180 & 500 \\
2 & $15: 00$ & 180 & 500 \\
\hline
\end{tabular}

Table 2. Instrumental Operating Conditions Using Thermo ICAP 6300 ICP-OES

\begin{tabular}{lcc}
\hline Parameter & Normal & Hydride System \\
\hline $\begin{array}{l}\text { Power } \\
\text { Pomp speed }\end{array} \begin{array}{lc}\text { Purge gas } \\
\text { Coolant Gas }\end{array}$ & $1150 \mathrm{~W}$ & $1350 \mathrm{~W}$ \\
& $50 \mathrm{rpm}$ & $30 \mathrm{rpm}$ \\
Flow & Argon & $16 \mathrm{~L} / \mathrm{min}$. \\
Auxiliary gas & & \\
\hline $\begin{array}{l}\text { Flow } \\
\text { Torch }\end{array}$ & $12 \mathrm{~L} / \mathrm{min}$. & $0.5 \mathrm{~L} / \mathrm{min}$. \\
Auto sampler & & Axial \\
\hline
\end{tabular}

The nearly $0.25 \mathrm{~g}$ dried and ground sample of grain barley was put into burning cup and $8 \mathrm{ml} \% 65 \mathrm{HNO}_{3}$ and $2 \mathrm{ml} \% 30 \mathrm{H}_{2} \mathrm{O}_{2}$ added on this grain samples. The samples were dissolved in a Milestone Smart D microwave oven according to program showing at Table 2. Soil sample was weighed $0.25 \mathrm{~g}$ in TFM containers and $6 \mathrm{ml} \% 65 \mathrm{HNO}_{3}, 1 \mathrm{ml} \% 30 \mathrm{H}_{2} \mathrm{O}_{2}$ and $3 \mathrm{ml} \% 40 \mathrm{HF}$ added (Table 1). After dissolving of soil sample $1,2 \mathrm{~g} \mathrm{H}_{3} \mathrm{BO}_{3}$ added in burning cup and dissolved.

Samples dissolved and diluted a certain volume with ultra-pure water (Elga ultra-Pure water system). The Concentrations were determined by ICP-OES (Thermo ICAP, 6300).

Total element concentration of soil was determined and showed in Table 3.

According to determined data in the soil Se content found below dedection limit. On the other hand, macro elements in the soil were showed normal 
concentration but micro element content such as $\mathrm{Fe}$ was found higher than other elements.

Table 3. Micro and trace element content in soil sample $(n=3$, mean \pm standart deviation, (mg/kg) dry weight)

\begin{tabular}{lccc}
\hline Elements & Soil & Elements & Soil \\
\hline $\mathrm{Ca}$ & $9550 \pm 33$ & $\mathrm{Cr}$ & $119 \pm 6$ \\
$\mathrm{~K}$ & $4083 \pm 44$ & $\mathrm{Cu}$ & $23.8 \pm 2.3$ \\
$\mathrm{Si}$ & $1971 \pm 32$ & $\mathrm{Sn}$ & $10.8 \pm 0.7$ \\
$\mathrm{Fe}$ & $16594 \pm 102$ & $\mathrm{~Pb}$ & $10.2 \pm 0.1$ \\
$\mathrm{Zn}$ & $44.5 \pm 1$ & $\mathrm{~V}$ & $70.6 \pm 6.8$ \\
$\mathrm{Mn}$ & $520 \pm 10$ & $\mathrm{As}$ & $8.92 \pm 0.32$ \\
$\mathrm{Ni}$ & $64.6 \pm 0.8$ & $\mathrm{Se}$ & $<0.0045$ \\
$\mathrm{Cd}$ & $0.56 \pm 0.01$ & & \\
\hline
\end{tabular}

\section{Statistical analysis (GT)}

The GT biblot analeyses were carried out using GT biplot software to assess micro and macro element content (Yan and Rajcan, 2002; Kendal et al., 2019). In multi-traits (MT) for cultivars, biplots were constructed by plotting the first two principal components (PC1 and PC2) derived from centered micro and macro element content data to singular value separation. Also, with the GT biplot analysis graphs in the study: It was aimed at revealing relation among examined micro and macro elements content and cultivars means by scatter plot (Fig. 1), and grouped micro and macro elements content and performance of each cultivars at each trait (Fig. 2), the stable and high performance of gcultivars micro and macro elements content by ranking model (Fig. 3), compare the desirable cultivars to ideal center based on micro and macro elements content by comparison model (Fig. 4).

\section{RESULTS AND DISCUSSION}

The result of element concentrations of barley cultivars showed in Table 4. According to these data, the concentrations of macro and trace elements were very variable in barley cultivars.

The consentration of $\mathrm{Ca}, \mathrm{Mg}, \mathrm{K}, \mathrm{Fe}, \mathrm{Cr}, \mathrm{V}$ and $\mathrm{Pb}$ were changed from $471-521 \mathrm{mg} \cdot \mathrm{kg}-1,637-846 \mathrm{mg} \cdot \mathrm{kg}-1,2611-3116 \mathrm{mg} \cdot \mathrm{kg}-1,36.6-68.7 \mathrm{mg} \cdot \mathrm{kg}-$ $1,0.55-0.97 \mathrm{mg} \cdot \mathrm{kg}-1,0.010-0110 \mathrm{mg} \cdot \mathrm{kg}-1,0.034-0140 \mathrm{mg} \cdot \mathrm{kg}-1$ respectivelly. The concentrations of these elements in Samyeli cultivar were higher than other three cultivars, while the concentration of $\mathrm{Si}(134 \mathrm{mg} / \mathrm{kg}$ 1) in Samyeli cultivar were quite lower. On the other hand, the concentration of Si $(239 \mathrm{mg} \cdot \mathrm{kg}-1)$ and $\mathrm{Cu}(5.83 \mathrm{mg} \cdot \mathrm{kg}-1)$ in Sur 93 were quite higher than other three cultivars, while the concentration of Vanadium content $(0.010 \mathrm{mg} \cdot \mathrm{kg}-1)$ in Sur-93 quite lower than other cultvars. Moreover, the concentration of Se was changed from 0.210$0.380 \mathrm{mg} \cdot \mathrm{kg} \mathrm{1}$, and the consentration of this element was higher in Alt1kat than other cultivars. Meanwhile Arsenic concentration of all cultivars found below, compare with dedection limits. The elements of $\mathrm{Pb}$ benefical for nutrition animal 
and human food. When the results of this study compare to other literature results, some elements concentration of barley taked from this study were higher and some of them were lower than other results and some of them were like some results of other studies. This differencies is normal, because these differences are estimated to be caused by climatic factors, varieties, genotypes, and soil factors (Ereifej et al., 2001 Salama and Radwan, 2005). On the other hand, Jâkobsone et al. (2018) reported that barley products can provide necessary macro and trace elements, especially of $\mathrm{Mn}, \mathrm{Mg}, \mathrm{Fe}$, and $\mathrm{Zn}(7.8-16.1 ; \quad 1024-1249 ; \quad 29.2-52.9$, and 20.5-33.7 $\mathrm{mg} \cdot \mathrm{kg}-1$, respectively). Jakobsone et al. (2015) reported that the obtained data from trace and macro elements will expand the opportunity for food and nutrition scientists to evaluate content of the examined elements in grain products, and dietary consumption (bioavailability) of the examined macroelements and trace elements.

Table 4. Concentrations of macro and trace elements in barley cultivars ( $\mathrm{n}=3$, mean \pm standart deviation, $(\mathrm{mg} / \mathrm{kg}$ ), dry weight)

\begin{tabular}{lllll}
\hline Elements(mg.kg & \multicolumn{4}{c}{ Cultivars } \\
\cline { 2 - 5 } & Altıat & Samyeli & Şahin-91 & Sur-93 \\
\hline $\mathrm{Ca}$ & $471 \pm 12$ & $521 \pm 15$ & $480 \pm 13$ & $488 \pm 8$ \\
$\mathrm{Na}$ & $449 \pm 39$ & $415 \pm 9.4$ & $415 \pm 8.5$ & $489 \pm 16$ \\
$\mathrm{Mg}$ & $637 \pm 14$ & $846 \pm 11$ & $720 \pm 90$ & $844 \pm 23$ \\
$\mathrm{~K}$ & $2837 \pm 172$ & $3116 \pm 78$ & $2611 \pm 153$ & $2547 \pm 143$ \\
$\mathrm{Si}$ & $160 \pm 35$ & $134 \pm 11$ & $171 \pm 12$ & $239 \pm 3$ \\
$\mathrm{Fe}$ & $36.6 \pm 5.6$ & $68.7 \pm 1.8$ & $38.3 \pm 2.4$ & $47.7 \pm 0.6$ \\
$\mathrm{Zn}$ & $19.4 \pm 0.2$ & $23.4 \pm 1$ & $28.4 \pm 0.25$ & $21.3 \pm 0.08$ \\
$\mathrm{Mn}$ & $13.7 \pm 0.07$ & $15.1 \pm 0.37$ & $14.2 \pm 1.3$ & $21.4 \pm 0.3$ \\
$\mathrm{Ni}$ & $0.53 \pm 0.07$ & $0.54 \pm 0.04$ & $0.44 \pm 0.01$ & $0.52 \pm 0.02$ \\
$\mathrm{Cd}$ & $0.041 \pm 0.004$ & $0.023 \pm 0.006$ & $0.029 \pm 0.006$ & $0.032 \pm 0.002$ \\
$\mathrm{Cr}$ & $0.55 \pm 0.02$ & $0.97 \pm 0.05$ & $0.55 \pm 0.004$ & $0.61 \pm 0.008$ \\
$\mathrm{Cu}$ & $3.90 \pm 0.3$ & $4.81 \pm 0.2$ & $4.47 \pm 0.45$ & $5.83 \pm 0.02$ \\
$\mathrm{Sn}$ & $16.6 \pm 0.7$ & $17.3 \pm 1.1$ & $18.3 \pm 1.8$ & $16.8 \pm 0.2$ \\
$\mathrm{~Pb}$ & $0.090 \pm 0.02$ & $0.140 \pm 0.01$ & $0.121 \pm 0.08$ & $0.034 \pm 0.01$ \\
$\mathrm{~V}$ & $0.090 \pm 0.005$ & $0.110 \pm 0.02$ & $0.063 \pm 0.006$ & $0.010 \pm 0.001$ \\
$\mathrm{As}$ & $<0.002$ & $<0.002$ & $<0.002$ & $<0.002$ \\
$\mathrm{Se}$ & $0.380 \pm 0.24$ & $0.210 \pm 0.2$ & $0.311 \pm 0.1$ & $0.312 \pm 0.12$ \\
\hline
\end{tabular}

Graphically the performance of cultivars based on macro and trace elements and correlation among macro and trace elements

Principal component analysis was used to show the distribution of cultivars based on macro and trace elements. The two-dimensional PCA score plot, derived from macro and trace elements and accounted for 78.37\% (45.32\% and 33.05\% for PC1 and PC2, respectively) of the total variation (Figs. 1-4).

The relationship each cultivar by each macro and trace element showed by cultivar vectors and macro and trace element vectors are drawn in Fig. 1, so that the specific interactions between a cultivar and a trait can be seen. 
Therefore, this figure can be used (1) to rank the cultivar based on performance in any trait, and (2) to rank macro and trace elements on the relative performance of any cultivar. The interpretation of performance a cultivar in a trait is better than average if the angle between its vector and the element's vector is $<90^{\circ}$; it is poorer than average if the angle is $>90^{\circ}$; and it is near average if the angle is about $90^{\circ}$ (Yan and Thinker, 2009; Dogan et al., 2016). The results of traits showed that there is high variation among cultivars based on elements. According to results, there was high correlation by $\mathrm{Zn}$ with $\mathrm{Sn}(\mathrm{r}=1.00), \mathrm{Cr}$ with $\mathrm{Ca}$ and $\mathrm{Fe}(\mathrm{r}=098), \mathrm{Ca}$ with $\mathrm{Fe}(\mathrm{r}=0.99)$ and $\mathrm{Pb}(0.45)$ was significant and positively, while V with Si ( $\mathrm{r}=-0.99)$ was significant and negatively (Fig.1; Table $5)$.

Moreover, Samyeli cultivar related with especially $\mathrm{Cr}$, Ca and Fe, Sur 93 related with $\mathrm{Mn}$ and $\mathrm{Cu}$, Alt1kat with $\mathrm{Se}, \mathrm{Cd}$ and Şahin 91 with $\mathrm{Zn}$ and $\mathrm{Sn}$ elements (Fig.1). On the other hand, the scatter plot indicated that three groups were occurred among macro and trace elements and cultivars showed a wide distribution on macro and trace element, and also The biplot indicated that three group occurred among macro and trace elements(Fig. 2). First group was occurred among $\mathrm{V}, \mathrm{Pb}, \mathrm{Sn}, \mathrm{Zn}, \mathrm{K}, \mathrm{Cr}, \mathrm{Ca}, \mathrm{Fe}, \mathrm{Mg}$ and related with Samyeli cultivar. The second group occurred among $\mathrm{Cu}, \mathrm{Mn}, \mathrm{Na}, \mathrm{Cd}$ and related with Sur 93 cultivar. The Altıkat and Şahin 91 did not related with any group of macro and trace elements (Fig1 and Fig 2).

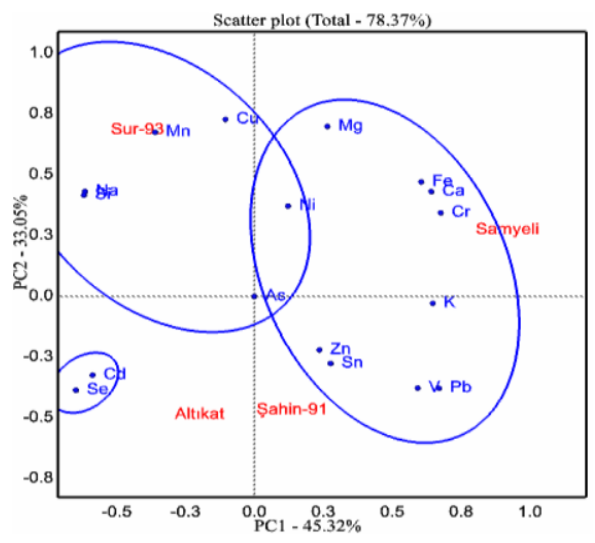

Figure 1. Relation among cultivars and macro and trace elements content.

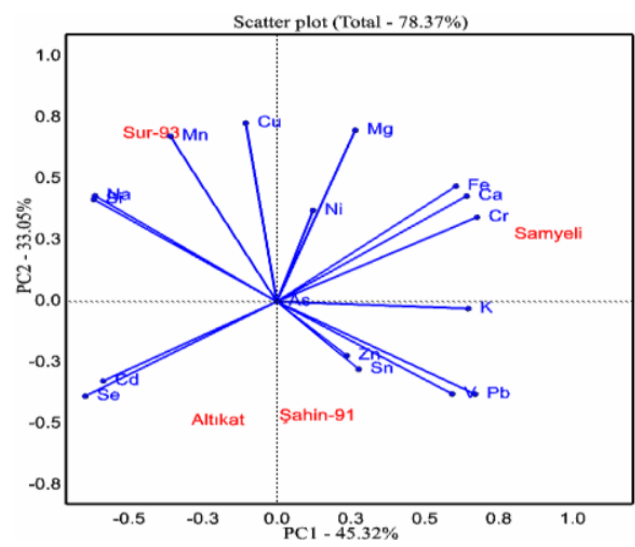

Figure 2. Groups of macro and trace elements content based on cultivars.

The third group occurred only $\mathrm{Cd}, \mathrm{Sa}$ and did not related with any cultivar. The GT biplot mainly allows the visualization of any crossover GT interaction, which is very important for the breeding program (Kilic et al., 2018).

The ranking biplot indicate that the cultivars located close to the origin of the coordinate system of the Biplot graph (Fig. 3) are considered more stable and the opposite is equivalent, the greater the distance from the origin, the less the 
stability based on mean of trace and macro elements (Kendal and Dogan, 2015). The Samyeli cultivar can be considered stable based on mean of trace and macro elements, when compared other cultivars, while, Altıkat and Şahin 91 were undesirable, because these two cultivar located under mean line of trace and macro elements, and Sur 93 was favorable but unstable because it was located far from origin of the coordinate line axis. Therefore, we can be used the Samyeli cultivar based on macro and trace elements for animal food.

Table 5: The correlation among trace and macro elements content

\begin{tabular}{|c|c|c|c|c|c|c|c|c|c|c|c|c|c|c|c|}
\hline & $\mathrm{Ca}$ & $\mathrm{Na}$ & $\mathrm{Mg}$ & $\mathrm{K}$ & $\mathrm{Si}$ & $\mathrm{Fe}$ & $\mathrm{Zn}$ & $\mathrm{Mn}$ & $\mathrm{Ni}$ & $\mathrm{Cd}$ & $\mathrm{Cr}$ & $\mathrm{Cu}$ & $\mathrm{Sn}$ & $\mathrm{Pb}$ & $\mathrm{V}$ \\
\hline \multicolumn{16}{|c|}{$\mathrm{Na}-0.34$} \\
\hline $\mathrm{Mg}$ & 0.79 & 0.17 & & & & & & & & & & & & & \\
\hline K & 0.68 & -0.55 & 50.12 & & & & & & & & & & & & \\
\hline $\mathrm{Si}$ & -0.37 & 0.87 & 0.28 & -0.83 & & & & & & & & & & & \\
\hline $\mathrm{Fe}$ & $0.99 * *$ & $*-0.25$ & 0.79 & 0.70 & -0.33 & & & & & & & & & & \\
\hline $\mathrm{Zn}$ & 0.08 & -0.62 & 20.08 & -0.23 & -0.16 & -0.05 & & & & & & & & & \\
\hline $\mathrm{Mn}$ & 0.10 & 0.82 & 0.67 & -0.50 & 0.88 & 0.15 & -0.26 & & & & & & & & \\
\hline $\mathrm{Ni}$ & 0.41 & 0.35 & 0.27 & 0.59 & -0.10 & 0.53 & -0.87 & 0.22 & & & & & & & \\
\hline $\mathrm{Cd}$ & -0.86 & 0.49 & -0.77 & -0.35 & 0.25 & -0.78 & -0.57 & -0.09 & 0.11 & & & & & & \\
\hline $\mathrm{Cr}$ & $0.98 *$ & -0.40 & 0.65 & 0.82 & -0.51 & $0.98 *$ & -0.04 & -0.05 & 0.52 & -0.75 & & & & & \\
\hline $\mathrm{Cu}$ & 0.41 & 0.56 & 0.88 & -0.32 & 0.70 & 0.43 & -0.03 & 0.93 & 0.17 & -0.45 & 0.24 & & & & \\
\hline Sn & 0.09 & -0.69 & 0.02 & -0.16 & -0.25 & -0.05 & $1.00 *$ & -0.35 & -0.86 & -0.55 & -0.01 & -0.12 & & & \\
\hline $\mathrm{Pb}$ & $0.45^{*}$ & -0.99 & -0.12 & 0.69 & -0.93 & 0.37 & 0.49 & -0.82 & -0.18 & -0.50 & 0.52 & -0.55 & 0.57 & & \\
\hline $\mathrm{V}$ & 0.37 & -0.78 & -0.28 & 0.89 & $-0.99 *$ & 0.36 & -0.01 & -0.84 & 0.25 & -0.17 & 0.53 & -0.69 & 0.09 & 0.86 & \\
\hline $\mathrm{Se}$ & -0.97 & 0.44 & -0.80 & -0.56 & 0.34 & -0.93 & -0.32 & -0.08 & -0.18 & 0.96 & -0.91 & -0.43 & -0.32 & -0.50 & -0.30 \\
\hline
\end{tabular}

The discriminating and representativeness of genotypes-based traits are visualizing the "ideal center" over the mean values of the environments and offers the opportunity to evaluate genotypes according to their proximity or distance to this center (Kendal, 2020). If the genotypes are located in the center, they are the most ideal, if they are located above the average vertical axis, but far from the center, it means that they are ideal, if they are located below vertical axis, it means that they are undesirable. Based on this overview the Fig. 4 explained that the Samyeli located near center of AEA, and so, it is more desirable than other cultivars, while Altıkat and Sahin 91 are the poorest cultivars, because these two cultivars are located under mean axis. The term "ideal genotype" is meaningful only when associated with mean performance. According to Fig. 4, the Samyeli is highly "ideal", Sur 93 is desirable genotypes, and because of Samyeli took places in center of AEA and Sur 93 took places on above averages of macro and trace elements axis, and so it means that it is just good for macro and trace elements. 


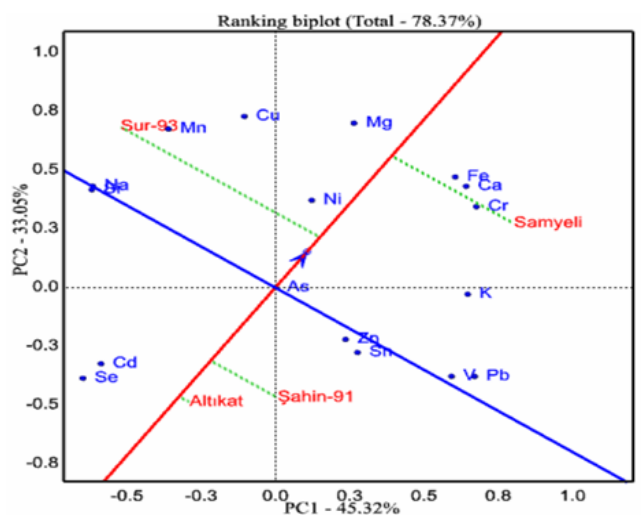

Figure 3. Ranking of cultivars based on macro and trace elements content.

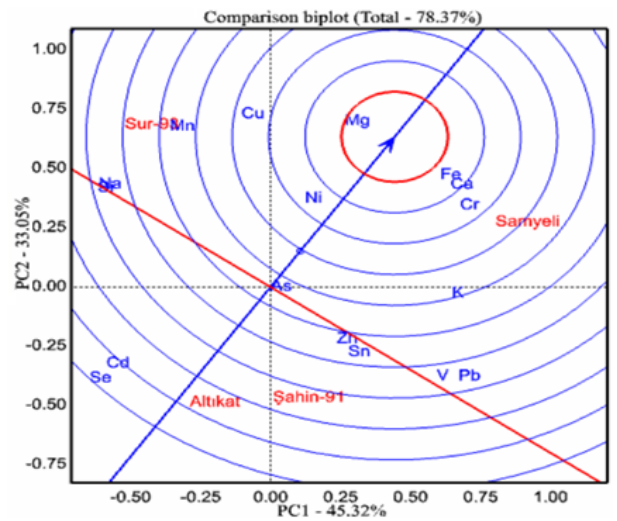

Figure 4. Comparison of cultivars based on macro and trace elements content

\section{CONCLUSIONS}

The According to result of study, there were differences among cultivars in terms of macro and trace elements. These differences are caused by climatic factors, varieties, cultivars, and soil factors. The study showed that Samyeli cultivar is the best in terms of majority macro and trace elements which examined in the study, while it was poor in terms of concentration of $\mathrm{Si}$. On the other hand, Sur 93 was good based on some macro and trace elements, while Şahin 91 and Alt1kat cultivars were poor based on majority macro and trace elements. The study showed that barley is importance to research and raise the quality of fattening. According to the biplot techniques indicated that there is high correlation between $\mathrm{Zn}$ with $\mathrm{Sn}$. Also, the study showed that the biplot technique is a very suitable method for visually understanding and evaluating the relationship between varieties and macro and trace elements.

\section{REFERENCES}

Abrahams PW. (2002): Soils: their implications to human health, Sci. Total Environ.291 $1-32$.

Adriano DC. (2001): Trace Elements in Terrestrial Environments. Biogeochemistry, Bioavailability and Risks of Metals, Springer-Verlag, New York.

Anonymus 1. http://extwprlegs1.fao.org/docs/html/tur33888.htm.

Bermudez GMA, Moreno M, Invernizzi R, Plá R, Pignata ML. (2010): Heavy metal pollution in topsoils near a cement plant: the role of organic matter and distance to the source to predict total and $\mathrm{HCl}$-extracted heavy metal concentrations, Chemosphere 78 375-381

Bradl HB. (2005): Heavy metals in the Environment: origin, interaction and remediation. Elsevier Academic press, $85 \mathrm{p}$ 
Cernohorsky T, Krejcova A, Pouzar M, Vavrusova L. (2008): Elemental analysis of flourbased ready-oven foods by slurry sampling inductively coupled plasma optical emission spectrometry Food Chemistry 106: 1246-1252

Chen T, Liu X, Zhu M, Zhao K, Wu J, Xu J, Huang P. (2008): Identification of trace element sources and associated risk assessment in vegetable soils of the urban-rural transitional area of Hangzhou, China. Environ Pollut 151:67-78.

Chojnacka K, Chojnacki A, Gorecka H, Gorecki H. (2005): Bioavailability of heavy metals from polluted soils to plants, Sci. Total Environ. 337, 175-182.

Cubadda F, Raggi A. (2005): Determination of cadmium, lead, iron, nickel and chromium in selected food matrices by plasma spectrometric techniques. Microchemical Journal 79, 91- 96.

Demirel S, Tuzen M, Saracoglu S, Soylak M. (2008): Evaluation of various digestion procedures for trace element contents of some food materials. J. of Hazardous Materials 152, 1020-1026.

Dogan Y, Kendal E, Oral E. (2016): Identifying of relationship between traits and grain yield in spring barley by GGE Biplot analysis. Agr. \& Forestry, 62(4): 239-252

Druteikienè R, Lukšienė B, Gvozdaitė R, (2002): Influence of soil factors on the vertical profile ofplutonium physicochemical forms//Ekologija Nr. 2,42-46, Vilnius.

Ereifej KI, Haddad SG. (2001): Chemical composition of selected jordanian cereals and legumes as compared with the FAO, Moroccan, East Asian and Latin American tables for use in the Middle East Trends in Food Science and Tecnology 11,374-378.

European Commission, Commission Regulation (EC) No. 466/2001 Setting Maximum Levels for Certain Contaminants in Foodstuffs, 2002.; US EPA, Risk Assessment Guidance for Superfund, Human Health Evaluation Manual (Part A). Interim Final, vol. I. Washington (DC), United States Environmental Protection Agency, EPA/540/1-89/002, 1989.

FAO/WHO, Contaminants, Codex Alimentarius, vol. XVII, Edition 1, FAO/WHO, Codex Alimentarius Commission, Rome.

Jākobsone I, Kantāne I, Zute S, Jansone I, Bartkevičs V. (2015): Macro-elements and trace elements in cereal grains cultivated in Latvia. In Proceedings of the Latvian Academy of Sciences. Section B. Natural, Exact, and Applied Sciences, 69 (4):152157.

Jākobsone I, Zute S, Bleidere M, Kantāne I, Bartkevičs V. (2018): Macro and trace elements in barley (Hordeum vulgare L.) breeds in Latvia depending on variety, environment, and agricultural practice. In Proceedings of the Latvian Academy of Sciences. Section B. Natural, Exact, and Applied Sciences, 72(2); 54-64.

Kabata-Pendias A, Mukherjee AB. (2007): Trace elements from soil to human, springerverlag, Berlin,

Kendal E and Dogan, Y. (2015): Stability of a candidate and cultivars (Hordeum vulgare L) by GGE Biplot analysis of multi-environment yield trials in spring barley. Agriculture \& Forestry, 61(4): 307-318. 
Kendal E, Doğan Y, Oral E, Koyuncu M. (2019): Investigating the quality of durum wheat landraces and determination of parents to use in breeding programs. Applied ecology and environmental research, 17(3):6031-6049.

Kendal E. (2020): Evaluation of some barley genotypes with geotype by yield* trait (GYT) biplot method. Agriculture \& Forestry, 66(2):137-150.

Khairiah J, Zalifah M K., Yin Y H, Aminah A, (2004): The uptake of heavy metals by fruit type vegetables grown in selected agricultural areas, Pakistan J. Biol. Sci. 7, 1438-1442.

Kilic H, Kendal E, Aktaş H. (2018): Evaluatıon of yield and some quality characters of winter barley (Hordeum vulgare L.) genotypes using biplot analysis. Agr. \& Forestry, 64(3): 101-111.

Markova Ruzdik N, Valcheva D, Valchev D, Mihajlov L, Karov I, Ilieva V, Ilievski M. (2015): Determination of some macro and micro elements in grain of winter barley genotypes. 19-20 May 2015, Stara Zagora, Bulgaria.

McLaughlin DR, Parker J, Clarke M. (1999): Metals and micronutrients - food safety issues, Field Crops Res M.J. 60 143-163.

Micó C, Recatalá L, Peris M, Sánchez J. (2006): Assessing heavy metal sources in agricultural soils of an European Mediterranean area by multivariate analysis. Chemosphere 65:863-872.

Mindel E. (2000): Vitaminova' bible pro 21. stolet1': Prague, Euromedia Group, Knižnı'klub

Pinto AP, Mota AM, de Varennes A, Pinto FC. (2004): Influence of organic matter on the uptake of cadmium, zinc, copper and iron by sorhum plants.Science of the Total Envir., 326 239-247.

Rana SVS. (2008): Metals and apoptosis: recent developments, J. Trace Elem. Med. Biol. 22 262-284.

Salama AK, Radwan M. (2005): Heavy metals (Cd, Pb) and trace elements $(\mathrm{Cu}, \mathrm{Zn})$ contents in some foodstuffs from the Egyptian market Emir. J. Agric. Sci., 17 (1): 34-42.

Schuhmacher M, Nadal M, Domingo JL. (2009): Environmental monitoring of PCDD/Fs and metals in the vicinity of a cement plant after using sewage sludge as a secondary fuel, Chemosphere 74 1502-1508.

Yan, W., Tinker, N.A. (2009): Biplot analysis of multi-environment trial data; Principles and applications. Canadian J. of P. Sci., 86: 623-645.

Yan W, and Rajcan I.R. (2002): Biplot analysis of test sites and trait relations of soybean in Ontario. Canadian Journal Plant Science. 42:11-20. 